\title{
The Effect of Tualang Honey on Human Periodontal Ligament Fibroblast Proliferation and Alkaline Phosphatase Level
}

(Kesan Madu Tualang ke atas Percambahan Fibroblas Ligamen Periodontium Manusia dan Paras Enzim Fosfatase Beralkali)

\author{
LAU Xin Yu, Haslina TAIB*,ZURAirah Berahim, AZlina AHMAD \& Siti LAILATUl AKMAR ZainUdDin
}

\begin{abstract}
Previous studies on honey have shown its potential as an alternative approach in optimizing medical resources for periodontal treatment. However, to date, there has been no study published on the effects of honey on human periodontal ligament fibroblasts (HPDLFS). The aimed of this study was to investigate the effect of Tualang honey on HPDLF proliferation and alkaline phosphatase (ALP) level with an intention to establish honey as one of the natural products which may promote healing and regeneration of periodontium. The HPDLFs were cultured and treated with honey at four different concentrations $\left(0.02,0.3,1\right.$ and 5\%) in a 96-well plate and incubated at $37^{\circ} \mathrm{C}$ with $5 \% \mathrm{CO}_{2}$. Proliferation test (MTT test) was assessed up to day 3 whereas ALP level (ALP assay) was assessed up to day 7. The amEM supplemented with $10 \%$ FBS and $1 \%$ penicillin streptomycin was used as control. The results for MTT showed that the cell proliferation for $0.02 \%$ honey concentration was significantly higher $(\mathrm{p}<0.05)$ on day 3 whereas the proliferation were decreased for $1 \%$ honey and $5 \%$ honey concentration $(\mathrm{p}<0.05)$ than control on all the 3 days. There was increased in ALP level in a similar pattern for all concentration groups from day 0 to day 7 without any significant difference compared with control. Therefore, the present data suggests that Tualang honey stimulated HPDLF proliferation at low concentrations and has an inhibitory effect at high concentrations. However, its role in osteoblastic differentiation requires further investigation.
\end{abstract}

Keywords: Alkaline phosphatase; cell proliferation; honey; human periodontal ligament fibroblasts

ABSTRAK

Kajian terdahulu tentang madu telah membuktikan kemampuannya sebagai pendekatan alternatif dalam mengoptimumkan sumber perubatan untuk rawatan periodontik. Walau bagaimanapun, sehingga kini, belum terdapat kajian yang diterbitkan tentang kesan madu ke atas fibroblas ligamen periodontium manusia (HPDLFS). Kajian ini bertujuan untuk mengkaji kesan madu Tualang ke atas percambahan HPDLF dan paras enzim fosfatase beralkali (ALP) dengan tujuan untuk menjadikan madu sebagai salah satu produk semula jadi yang boleh menggalakkan penyembuhan dan pertumbuhan semula periodontium. HPDLFs dikultur dan dirawat dengan madu pada empat kepekatan berbeza $(0.02,0.3,1$ dan 5\%) pada plat 96-takung dan dieram pada $37^{\circ} \mathrm{C}$ dengan $5 \% \mathrm{CO}_{2}$. Ujian percambahan (ujian MTT) telah dinilai sehingga hari ke-3 manakala tahap ALP (ALP cerakin) telah dinilai sehingga hari ke- 7. AMEM yang ditambah dengan 10\% FBS dan $1 \%$ penisilin streptomisin digunakan sebagai kawalan. Keputusan untuk MTT menunjukkan percambahan sel bagi kepekatan madu $0.02 \%$ adalah jauh lebih tinggi $(\mathrm{p}<0.05)$ pada hari ke-3 manakala percambahan telah menurun untuk $1 \%$ madu dan $5 \%$ kepekatan madu $(\mathrm{p}<0.05)$ berbanding kawalan pada 3 hari tersebut. Terdapat peningkatan pada tahap ALP dalam pola yang sama bagi semua kumpulan kepekatan daripada hari 0 hingga hari ke-7 tanpa sebarang perbezaan yang signifikan berbanding dengan kawalan. Oleh itu, data yang diperoleh mencadangkan bahawa madu Tualang telah merangsang percambahan HPDLF pada kepekatan yang rendah dan mempunyai kesan pembantutan pada kepekatan yang tinggi. Walau bagaimanapun, peranannya dalam pembezaan osteoblas memerlukan kajian lanjut.

Kata kunci: Fibroblas ligamen periodontium manusia; fosfatase beralkali; madu; percambahan sel

\section{INTRODUCTION}

Honey is a substance produced by bees using nectar and sweet deposits from plants (Kannan et al.2009). It is acidic in nature ( $\mathrm{pH} 4)$ and consists of $80 \%$ sugars (fructose, glucose, sucrose, and maltose), 17-20\% water and 4\% of other substances (pollen grains, enzymes, hydrogen peroxide, amino acids, organic acids, polyphenols, vitamins and minerals). Though the exact biochemical mechanism remains unclear, studies have shown that honey has anti-inflammatory, anti-oxidant, apoptotic and immunomodulatory properties (Hassan et al. 2010). In addition, honey accelerates wound healing by forming new tissues and also has antimicrobial properties (Kannan et al. 2009).

The anti-inflammatory action of honey makes it a potential therapeutic agent for periodontal diseases as periodontal tissue destruction is mainly due to the inflammatory and immune reactions of the host (Molan 
et al. 2001). Among all the cell populations involved in periodontal wound healing, periodontal ligament fibroblasts (PDLFs) have been regarded as one of the most important cells for maintaining the periodontium (Choi et al. 2010). This is because they are believed to regenerate the main components of periodontal tissue, namely the cementum, periodontal ligament and alveolar bone (Kontonasaki et al. 2007).

Malaysian Tualang honey is collected from the tualang tree (Koompassia excelsa), where Asian rock bees (Apis dorsata) build their hives. Tualang honey is locally used as food or as a medicinal product (Tan et al. 2009). It is also reported to have antibacterial properties against various microorganisms, such as Pseudomonas sp. and MRSA (Nasir et al. 2010).

In the initial differentiation stage, periodontal ligament cells have been known to express alkaline phosphatase (ALP), which is also one of the initial differentiation markers of osteoblasts. Therefore, ALP level was investigated to evaluate the differentiation of PDLFs (Choi et al. 2010).

Until recently, reports on the effect of honey on periodontal ligament cells are still limited. There has been substantial work on the beneficial effects of honey and it can potentially be as an alternative approach in optimizing medicinal resources to treat periodontal diseases. Further work is needed in regeneration-based treatment of periodontal diseases (Kasaj et al. 2008). Therefore, this study aimed to investigate the effect of honey on human periodontal ligament fibroblasts (HPDLFs) proliferation and ALP level, as the established medicinal properties of honey may prove beneficial to the healing and regeneration of the periodontium.

\section{MATERIALS AND METHODS}

HONEY

Tualang honey manufactured by Federal Agriculture Marketing Authority (FAMA), Malaysia was used in this study.

\section{CELLS}

Primary HPDLFs (2630, ScienCell, USA) were purchased from ScienCell Research Laboratories, USA.

\section{CHEMICALS}

Alpha Minimal Essential Medium ( $\alpha$ MEM) with L-glutamine, ribonucleosides and deoxyribonucleosides (12571, Gibco, USA), fetal bovine serum (FBS) (10270, Gibco, USA), trypsin (TrypLE ${ }^{\mathrm{TM}}$ Express, Gibco, USA), penicillin and streptomycin (15140, Gibco, USA), MTT (475989, Calbiochem, USA), dimethyl sulfoxide (DMSO) (1.02952.1000, Merck, Germany), Alkaline Phospatase (ALP) kit, (AP311, Randox, UK).

\section{CELL CULTURE}

The HPDLFs (2630, ScienCell, USA) were cultured in QMEM supplemented with $10 \%$ FBS, $1 \%$ penicillin and streptomycin, at $37^{\circ} \mathrm{C}$ in a humidified incubator in the presence of $5 \% \mathrm{CO}_{2}$.

\section{CELL PROLIFERATION ASSAY (MTT TEST)}

A 3-(4,5-Dimethyl-2-thiazolyl)-2,5-diphenyl-2Htetrazolium bromide (МTT) assay was performed to assess the cell proliferation based on a modification of the method described by Kannan et al. (2009). The HPDLFs were plated in a 96-well plate at a density of 5000 cells/ well in $200 \mu \mathrm{L}$ medium each and were allowed to attach for $24 \mathrm{~h}$ before being treated with different concentrations of honey $(0.02,0.3,1$ and $5 \%)$. The aMEM supplemented with $10 \%$ FBS and $1 \%$ penicillin streptomycin was used as a control. The cells were observed under light microscope for day 0 to day 3 . All groups were incubated at $37^{\circ} \mathrm{C}$ in a humidified incubator in the presence of $5 \% \mathrm{CO}_{2}$ for 1 , 2 and 3 days. After the incubation period, $30 \mu \mathrm{L}$ of MTT solution (prepared with phosphate-buffered saline to a concentration of $5 \mathrm{mg} / \mathrm{mL}$ and filtered) was added into each well and further incubated for $4 \mathrm{~h}$. After that, the medium with excess MTT was removed from the wells and $200 \mu \mathrm{L}$ of dimethyl sulfoxide (DMSO) was added to dissolve the dark blue formazan crystals formed by viable cells. To ensure that all crystals were dissolved, the plates were further incubated for $1 \mathrm{~h}$ and shaken for $3 \mathrm{~min}$ before the measurement of absorbance was taken using an ELISA plate reader (TECAN Sunrise Absorbance Reader, Austria) at a wavelength of $570 \mathrm{~nm}$ with $600 \mathrm{~nm}$ as reference.

\section{ALKALINE PHOSPHATASE (ALP) ASSAY}

The HPDLFs were plated at a density of 5000 cells/well in $200 \mu \mathrm{L}$ medium/well in a 96-well culture plate and were allowed to attach for $24 \mathrm{~h}$ before being treated with different concentrations of honey $(0.02,0.3,1$ and $5 \%)$. The aMEM supplemented with $10 \%$ FBS and $1 \%$ penicillin streptomycin was used as a control. All groups were incubated at $37^{\circ} \mathrm{C}$ in a humidified incubator in the presence of $5 \% \mathrm{CO}_{2}$ for $1,3,5$ and 7 days. After the incubation period, the medium in each well was removed and placed in a labelled vial. The vials were then stored frozen at $-70^{\circ} \mathrm{C}$. The ALP reagent was prepared according to manufacturer's instructions by adding $10 \mathrm{~mL}$ of buffer solution and 100 $\mu \mathrm{L}$ of magnesium ion solution to the substrate for each series of tests. On day 8, the frozen vials were thawed to room temperature and the ALP test performed by adding 20 $\mu \mathrm{L}$ of test medium from the vial into a cuvette containing $1 \mathrm{~mL}$ of freshly prepared ALP reagent. After mixing, the absorbance is read with a spectrophotometer (CECIL CE 20212000 Series, Cambridge, UK) at $405 \mathrm{~nm}$ in 0, 1,2 and $3 \mathrm{~min}$. The mean change in absorbance per minute $(\Delta \mathrm{A} /$ min) is determined and the ALP level was calculated using the following formula: 


$$
* \mathrm{U} / \mathrm{l}=2742 \times \text { mean } \Delta \mathrm{A} / \mathrm{min}
$$

*The activity of enzyme which converts $1 \mu \mathrm{mol}$ of substrate into product in $1 \mathrm{~min}$ at standard conditions is the international enzyme unit (U).

\section{STATISTICAL ANALYSIS}

The statistical analysis was performed using SPSS software (PASW Statistics 18, SPSS Inc., Chicago, IL). The KruskalWallis one-way analysis of variance by ranks and Wilcoxon signed-rank test was used for comparison of HPDLF proliferation and ALP level among groups of cells treated with different concentrations of honey. The statistical significance was set at $p<0.05$.

\section{RESULTS}

\section{HPDLF PROLIFERATION UNDER LIGHT MICROSCOPE} FROM DAY 0 TO DAY 3

Cells with $0.02 \%$ honey (D, E and F) showed good attachment on the culture plate by showing spreading of filopodia. The numbers of cells also seem to be increased from day 0 to day 3 . This is in contrast with the cells in the $5 \%$ honey concentration $(\mathrm{G}, \mathrm{H}$ and $\mathrm{I})$ where the cells become rounded and floated inside the culture plate, which is a sign of dying cells (Figure 1).

\section{CELL PROLIFERATION ASSAY (MTT TEST)}

The percentage of cell proliferation in four different concentrations of honey for day 1 to day 3 is shown in
Figure 2. The highest percentage of cell proliferation was observed in $0.02 \%$ honey concentration in QMEM supplemented with $10 \%$ FBS and $1 \%$ penicillin/ streptomycin at day 3. It promotes $127.2 \%$ increment of cell proliferation than control, whereas cell proliferation were decreased to $100.5 \%$ and $94.3 \%$ for $0.30 \%$ and $1.0 \%$ honey concentration in $\alpha$ MEM supplemented with $10 \%$ FBS and $1 \%$ penicillin/streptomycin, respectively. There was significantly decreased of cell proliferation in $5.0 \%$ concentration of honey $(p=0.002)$ which showed an inhibition of HPDLFs to more than $50 \%$ compared to control for day 1 to day 3 .

\section{ALKALINE PHOSPHATASE (ALP) ASSAY}

There was increase in ALP level in a similar pattern for all concentration groups from day 0 to day 7 without any significant difference compared with control. Except for day $1,0.02 \%$ honey showed higher ALP level than control throughout the incubation period although it was not statistically significant (Figure 3).

\section{DISCUSSION}

Honey has been traditionally used to promote health and fight disease for centuries. The observed biological activities of honey may be due to its chemical constituents and high sugar content (Hassan et al. 2010). Most literature reported on the effect of honey treatment on external wounds rather than lesions and infections of mucosal surfaces, but the features observed are relevant also to many aspects of dental practice, such as removing

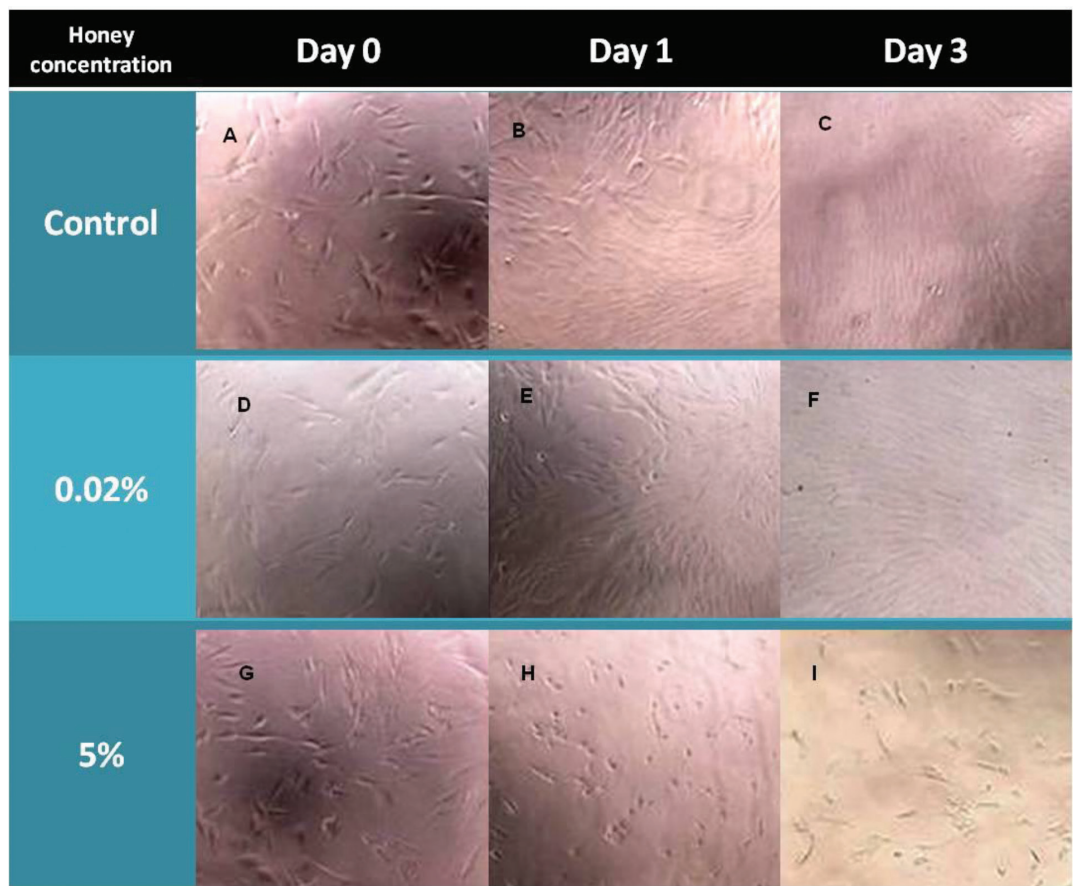

FIGURE 1. Human periodontal ligament fibroblast cells under light microscope at $10 \times$ magnification 


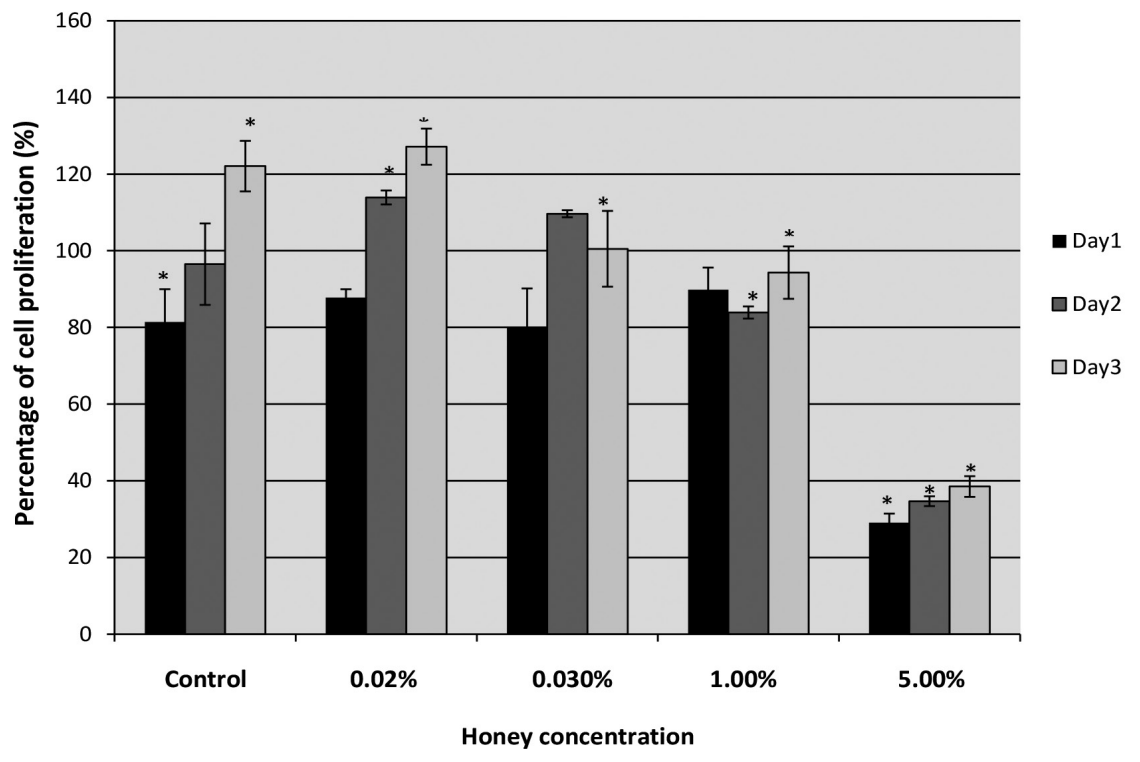

FIGURE 2. Percentage of cell proliferation of human periodontal ligament fibroblast cell line for different concentration of Tualang honey

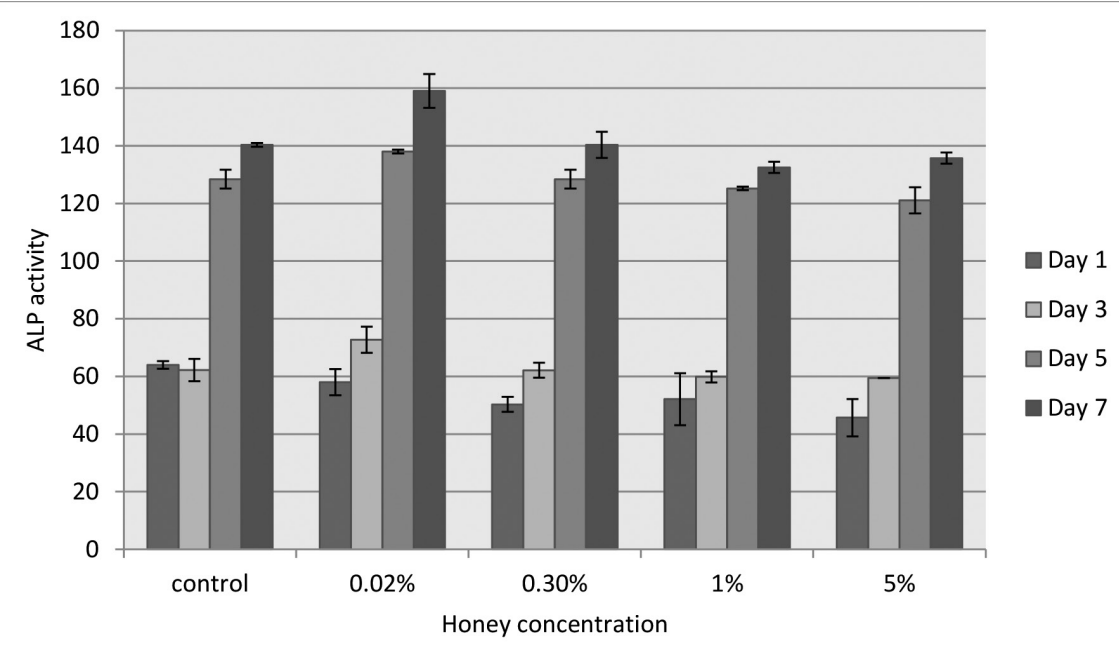

FIGURE 3. Alkaline phosphatase level of the human periodontal ligament fibroblast cell line after treated with different concentrations of Tualang honey $* p<0.05$ is significant

malodour, reducing pain and inflammation as well as promoting healing (Molan et al. 2001).

In periodontal therapy, the final aim is to control periodontal tissue inflammation and produce predictable regeneration of periodontium lost due to periodontal disease. Different treatment approaches to repopulate area of lost periodontal structure by desirable cells have been suggested (Kasaj et al. 2008). Previous studies showed that the periodontal ligament provides fibroblastic cells implicated in periodontal tissue regeneration and repair during wound healing (Kontonasaki et al. 2007). However, studies investigating the effect of honey on HPDLFs are scarce. Reports on the proliferation and differentiation of PDLF in general are only a few (Choi et al. 2010).

In the present study, we found that $0.02 \%$ honey promoted significantly higher HPDLF proliferation compared with control. This is consistent with the findings of Kannan et al. (2009) where the highest cell proliferation for human osteoblast cell lines was also seen at $0.0195 \%$ honey in DMEM supplemented with $10 \%$ FBS and $1 \%$ penicillin streptomycin, after $72 \mathrm{~h}$ of incubation. In another study, Abuharfeil et al. (1999) found that low concentrations of honey $(0.1$ and $0.2 \%)$ stimulated lymphocyte proliferation and activated phagocytes. Enhanced proliferation induced by honey may be a nutritional effect, caused by the carbohydrate content of honey which is the substrate for glycolysis (Rady \& Yahya 2011). It can be deduced that honey can promote periodontal wound healing by stimulating proliferation of HPDLFS.

Kannan et al. (2009) reported that cell proliferation decreased in a dose-dependent manner. This is similar to 
our finding that at high concentrations (5\%), honey was seen to inhibit HPDLFs proliferation. As shown in Figure 1 , the inhibition of cells could be observed as more cells became rounded and floating in the culture medium of $5 \%$ honey concentration. The reason for this could be the acidic nature of honey or its hyperosmolarity. In a study to identify and quantify trace elements in wild and orchard honey, both samples presented a pH of 4.5 (Almeida-Silva et al. 2011). Honey's acidic pH may cause unpleasant or even painful feelings during application or ingestion (Werner et al. 2011). Propolis, another substance made by the honey bee was found by de Funari et al. (2007) to be toxic to mouse dermal fibroblasts at high concentrations ( $31.25 \mu \mathrm{g}$ / $\mathrm{mL}$ or more) as well. Therefore, further clinical studies are needed to determine the optimal dosage and concentration of honey for proliferation of periodontal cells.

From the present study, it was observed that ALP level for all concentration groups increased without any significant difference with control. This finding is consistent with that of Rady and Yahya (2011) where crude honey (Sider Kashmiry honey and Madina bee honey) insignificantly increased ALP level in hepatocellular carcinoma cell lines. In a study comparing HPDLFs and human alveolar bone cells (HBACs), ALP were not detected during the proliferative phase of HPDLFs and HBACs. However, at the confluent stage, ALP synthesized by HPDLFs was similar to HBACs (Kawase et al. 1988). This shows that ALP is expressed in mature HPDLFs and is an initial differentiation marker. However, based on this experiment, it may be inferred that within seven days, the supplement of honey exclusively does not have a significant role in stimulating osteoblastic differentiation in HPDLFs. Nevertheless, further study is needed to elucidate this finding.

\section{CONCLUSION}

In conclusion, the present data suggests that Tualang honey stimulated HPDLF proliferation at low concentrations but has an inhibitory effect at high concentrations. It may not play a role in promoting osteoblastic differentiation in 7 days, therefore longer study duration is needed for more comprehensive findings.

\section{ACKNOWLEDGEMENTS}

The authors would like to express their appreciation to Professor Dr. Siti Amrah Sulaiman, for her support in honey research and the staff at Craniofacial Science Laboratory, School of Dental Sciences, Universiti Sains Malaysia for their kind assistance throughout the duration of this research as well as FAMA Negeri Kedah, Malaysia for providing the Tualang honey. This study was supported by USM Incentive Grant.

\section{REFERENCES}

Abuharfeil, N.,Al-Oran, R. \& Abo-Shehada, M. 1999. The effect of bee honey on the proliferative activity of human B-and
T-lymphocytes and the activity of phagocytes. Food and Agricultural Immunology 11(2): 169-177.

Almeida-Silva, M., Canha, N., Galinha, C., Dung, H.M., Freitas, M.C. \& Sitoe, T. 2011. Trace elements in wild and orchard honeys. Applied Radiation and Isotopes 69: 1592-1595.

Choi, E.J., Yim, J.Y., Koo, K.T., Seol, Y.J., Lee, Y.M., Ku, Y., Rhyu, I.C., Chung, C.P. \& Kim, T.I. 2010. Biological effects of a semiconductor diode laser on human periodontal ligament fibroblasts. J. Periodontal Implant Sci.40: 105-110. de Funari, C.S., de Oliveira Ferro, V. \& Mathor, M.B. 2007. Analysis of propolis from Baccharis dracunculifolia DC. (compositae) and its effects on mouse fibroblasts. Journal of Ethnopharmacology 111(2): 206-212.

Hassan, M.I., Mabrouk, G.M., Shehata, H.H. \& Aboelhussein, M.M. 2010. Antineoplastic effects of bee honey and Nigella sativa on hepatocellular carcinoma cells. Integr. Cancer Ther. 11(4): 354-363.

Kannan, T.P., Abdulaziz, Q.A., Siti Fadilah, A. \& Azlina, A. 2009. Evaluation of Tualang honey as a supplement to fetal bovine serum in cell culture. Food and Chemical Toxicology 47: 1696-1702.

Kasaj, A., Willershausen, B., Reichert, C., Kasaj, A.G., Zafiropoulos, G.G. \& Schmidt, M. 2008. Human periodontal fibroblast response to a nanostructured hydroxyapatite bone replacement graft in vitro. Archives of Oral Biology 53: 683-689.

Kawase, T., Sato, S., Miake, K. \& Saito, S. 1988. Alkaline phosphatase of human periodontal ligament fibroblast-like cells. Adv. Dent. Res. 2(2): 234-239.

Kontonasaki, E., Sivropoulou, A., Papadopoulou, L., Garefis, P., Paraskevopouloss, K. \& Koidis, P. 2007. Attachment and proliferation of human periodontal ligament fibroblasts on bioactive glass modified ceramics. Journal of Oral Rehabilitation 34: 57-67.

Molan, P.C. 2001. The potential of honey to promote oral wellness. Gen. Dent. 49(6): 584-589.

Nasir, N.M., Halim, A.S., Singh, K.B., Dorai, A.A. \& Haneef, M.M. 2010. Antibacterial properties of Tualang honey and its effect in burn wound management: A comparative study. BMC Complementary and Alternative Medicine 10: 31 .

Rady, H.M. \& Yahya, S.M.M. 2011. Enhancement of the antitumor effect of honey and some of its extracts using adiponectin hormone. Australian Journal of Basic and Applied Sciences 5(6): 100-108.

Tan, H.T., Rahman, R.A., Gan, S.H., Halim, A.S., Hassan, S.A., Sulaiman, S.A. \& Singh, K.B. 2009. The antibacterial properties of Malaysian Tualang honey against wound and enteric microorganisms in comparison to Manuka honey. BMC Complementary and Alternative Medicine 9: 34.

Werner, A. \& Laccourreye, O. 2010. Honey in otorhinolaryngology: When, why and how. European Annals of Otorhinolaryngology, Head and Neck Diseases 128: 133-137.

School of Dental Sciences

Universiti Sains Malaysia

16150 Kubang Kerian, Kelantan

Malaysia

*Corresponding author; email: haslinakk@usm.my

Received: 13 January 2014

Accepted: 4 March 2015 